\title{
BIMBINGAN PENYULUHAN TERHADAP PEMAHAMAN ORANG TUADALAM MENCEGAH STUNTING PADA ANAK USIA DINI
}

\author{
Nihwan \\ Institut Agama Islam Negeri (IAIN) Metro \\ Jl. Ki Hadjar Dewantara 15 A Kota Metro Lampung 34111 \\ Email: Nihwan@gmail.com
}

\begin{abstract}
Stunting is a condition of malnutrition status that is chronic in the period of growth and development since the beginning of life. One effort in the prevention of Stunting in early childhood is through increasing knowledge, attitudes and behavior about nutritional counseling. Therefore, to prevent stunting in children, mothers need to consume proper nutrition, especially during pregnancy until the child is born and is 18 months old. Parents' knowledge about nutritional health and food support for child nutrition needs to be conducted by conducting counseling, counseling, parenting programs and maximizing posyandu. With this kind of activity, of course parents will pay more attention to health and nutritional needs for children in the golden age of their development.Understanding of balanced nutrition in early childhood is also a trigger to prevent Stunting, so parents are able to understand food and nutrition needs for children according to their developmental stages. By doing guidance and counseling effectively in understanding Stunting problems in children, parents will pay more attention to Nutrition and Nutrition in early childhood.
\end{abstract}

Keywoard: Guidance, Counseling, Stunting, Children 


\section{A. PENDAHULUAN}

Stunting adalah suatu kondisi status gizi kurang yang bersifat kronik pada masa pertumbuhan dan perkembangan sejak awal kehidupan. Dikatakan oleh WHO stunting dikondisikan dengan nilai Z-score tinggi badan menurut umur (TB/U) kurang dari -2 standar deviasi (SD). Secara global, sekitar 1 dari 4 anakusiadinimengalami stunting. ${ }^{1}$ Kejadian stunting sering dijumpai pada anak usia 12-36 bulan dengan prevalensi sebesar $38,3-41,5 \%$. Stunting pada anak usia dibawah lima tahun biasanya kurang disadari karena perbedaan anak yang stunting dengan anak yang normal pada usia tersebut tidak terlalu dilihat. Usia di bawah lima tahun merupakan periode emas dalam menentukan kualitas sumber daya manusia yang dilihat dari segi pertumbuhan fisik maupun kecerdasan, sehingga hal ini harus didukung oleh status gizi yang baik. Seorang anak yang mengalami stunting pada masa ini cenderung akan sulit mencapai tinggi badan yang optimal pada periode selanjutnya. Hal ini dapat menyebabkan gangguan perkembangan fungsi kognitif dan psikomotor, penurunan intelektual peningkatan risiko penyakit degeneratif serta penurunan produktivitas di masa mendatang. ${ }^{2}$

Kondisi stunting sulit ditangani bila anak telah memasuki usia dua tahun. Oleh karena itu, untuk mencegah terjadinya stunting pada anak, ibu perlu mengonsumsi asupan gizi yang layak, terutama selama masa kehamilan hingga anak lahir dan berusia 18 bulan. Pada dasarnya, kelangsungan hidup dan kesehatan anak tidak dapat dipisahkan dari kesehatan ibu. Asupan zat gizi yang rendah dipengaruhi oleh pola asuh, salah satunya adalah perilaku pemberian makan yang tidak tepat. Penelitian menyebutkan adanya hubungan yang nyata antara pola pengasuhan

${ }^{1}$ Astari Ld, Nasoetion A \& Dwiriani CM, Hubungan Antara Keluarga dan Anak dalam Menangani Masalah Stunting Usia 6-12 Bulan, Media Gizi Dan Keluarga. 2005; 29: 40-46

${ }^{2}$ Adani, V., Pangestuti, D. R. \& Raflihudin, M. Z. Hubungan asupan makanan (karbohidrat, protein, dan lemak) dengan status gizi bayi dan balita ( studi pada taman penitipan anak lusendra Kota Semarang Tahun 2016). Jurnal Kesehatan Masyarakat. 2016 ; 4:261-271 
dengan stunting. ${ }^{3}$ Perilaku pemberian makanan balita dipengaruhi oleh pengetahuan gizi ibu. Pengetahuan gizi ibu adalah salah satu faktor yang mempunyai pengaruh signifikan pada kejadian stunting. ${ }^{4}$ Oleh karena itu, upaya perbaikan stunting dapat dilakukan dengan peningkatan pengetahuan sehingga dapat memperbaiki perilaku pemberian makan pada anak. Salah satu upaya peningkatan pengetahuan untuk merubah perilaku pemberian makan pada anak yaitu dengan konseling gizi. Konseling maupun penyuluhan dalam memahamkan orang tua agar mengetahui sejak dini masalah penyebab Stunting maka akan memberikan pengetahuan orang tua sehingga mampu melakukan tindakan dalam mencegah Stunting sedini mungkin.

Selain panjang badan lahir, status ekonomi keluarga juga merupakan faktor risiko kejadian stunting pada balita. Penelitian di Brazil menunjukkan bahwa prevalensi stunting mengalami penurunan dari 34\% pada Tahun 1986 menjadi 6\% pada Tahun 2006. Hal ini disebabkan peningkatan kualitas perekonomian di negara itu selama 2 dekade tersebut. ${ }^{5}$ Banyak penelitian pada keluarga miskin di negara berkembang menemukan adanya anak-anak yang pertumbuhan tinggi badannya tidak optimal, bahkan sejak masih bayi, namun perkembangan berat badannya baik. ${ }^{6}$ Penelitian di Libya menemukan bahwa status sosial ekonomi keluarga (berasal dari keluarga kurang mampu) bukan faktor utama kejadian stunting karena dapat tertutupi oleh faktor lain seperti pengetahuan, sumber daya dan kebiasaan hidup masyarakat setempat (custom atau adat), sehingga mampu

${ }^{3}$ AstariLd, Nasoetion A \& Dwiriani Cm, Correlation between breastmilk consumption wirh stunting prevalences among children 6-12 months old in bogor municipality, Media Gizi Dan Keluarga. 2006; 30: 1523

${ }^{4}$ Notoatmodjo, Promosi kesehatan teori dan aplikasi, Jakarta: Rineka Cipta; 2005 hal. 28

${ }^{5}$ El Taguri A, Betilmal I, Mahmud Sm, Ahmed Am, Goulet O, Galan P \& Hercberg S, Risk factor for stunting among under-fives in Libya, Public Health Nutrition. 2008; 12: 1141-1149

Ibid ... hal. 1196-1204 
mempertahankan kesehatan dan status gizi meskipun berada di lingkungan yang sulit.

Suatu penelitian menyebutkan bahwa pada ibu yang memiliki anak berstatus gizi lebih adalah sebesar $51,7 \%$ ibu memiliki persepsi anaknya gemuk, sedangkan sebesar $45 \%$ ibu yang memiliki anak berstatus gizi lebih mempunyai persepsi bahwa ukuran tubuh anak normal. Hal ini membuktikan bahwa terjadi perbedaan persepsi pada ibu tentang status gizi anaknya. Jika anak mempunyai status gizi lebih, akan mengganggu aktivitasnya dan mengakibatkan risiko penyakit degeneratif, seperti jantung koroner, diabetes mellitus, hipertensi, dll, sedangkan jika anak mengalami kurang gizi, akan menurunnya daya tahan tubuh anak, postur tubuh anak menjadi pendek, perilakunya menjadi tidak tenang, mudah tersinggung, dan cengeng.

Penelitian di Semarang pada anak usia 12-36 bulan menunjukkan bahwa status ekonomi keluarga dan kurangnya pemahaman orang tua terhadap kesehatan gizi anak adalah faktor risiko kejadian stunting. ${ }^{7}$ Pengetahuan orang tua mengenai kesehatan gizi dan makanan pendukung gizi anak perlu dilakukan penngarahan seperti dengan melaksanakan konseling, penyuluhan, program parenting dan memaksimalkan posyandu. Dengan kegiatan semacam ini tentu orang tua akan lebih memperhatikan kesehatan dan kebutuhan gizi bagi anak pada masa keemasan perkembangannya. Penelitian di Kalimantan Barat menunjukkan bahwa pekerjaan ibu, jumlah anggota keluarga dan pendapatan total keluarga merupakan faktor risiko stunting pada balita, sedangkan pekerjaan ayah, pendidikan ibu dan pengetahuan gizi ibu merupakan faktor risiko stunting. ${ }^{8}$ Penelitian terdahulu tentang stunting banyak yang mengkaji tentang kandungan gizi balita stunting, dan masih relatif sedikit penelitian tentang stunting yang mengkaji dari

${ }^{7}$ Handayani, Oktia WK. Rahayu, Sri R. Hermawati, Efektifitas Kepemimpinan dan Optimalisasi Potensi Lokal untuk Membangun Lingkungan Sadar Nutrisi, Jurnal Kesehatan Masyarakat. 2018; 3: 423-429.

${ }^{8}$ Kementrian Kesehatan RI Keputusan Menteri Kesehatan Republik Indonesia: Standar Antropometri Penilaian Status Gizi Anak. Jakarta; 2011 
aspek sosial terutama yang berkaitan dengan pengetahuan, persespsi ibu tentang kejadian stunting.

Peran orang tua dalam menangani masalah Stunting sejak dini menjadi hal yang harus agar mampu mengurangi dan meminimalisir kejadian Stunting pada anak usia dini. Pengetahuan orang tua tentang deteksi dan penanganan awal agar anak tidak mengalami Stunting mampu memberikan efek perubahan pola pentingnya memperhatikan perkembangan pada anak usia dini. Pemahaman tentang gizi seimbang pada anak usia dini juga menjadi pemicu mencegah terjadinya Stunting, sehingga orang tua mampu memahami kebutuhan makanan dan gizi bagi anak sesuai dengan tahap perkembangannya. Dengan melakukan bimbingan dan penyuluhan secara efektif dalam memahamkan masalah Stunting pada anak, maka para orang tua akan lebih memperhatikan Nutrisi dan Gizi pada masa usia dini. Kegiatan ini akan mampu memberikan pemahaman yang cukup terhadap orang tua, sehingga untuk mencegah terjadinya Stunting pada anak usia dini bisa maksimal.

\section{B. MASA PERKEMBANGAN ANAK}

Perkembanganadalah bertambahnyakemampuan ( skill ) dalam struktur dan fungsi tubuhyang lebihkomkleks dalam polayang teratur dan dapat diramalkan sebagai hasil dari proses pematangan Perkembangan menyangkut adanya proses diferensiasi dari sel - sel tubuh, jaringan tubuh, organ dan sistem organ yang berkembang sedemikian rupa sehingga masing masing dapat memenuhi fungsinya, termasukjuga perkembanganemosi, intelektual dan tinggkah lakusebagai hasil interaksi dengan lingkungannya. Peristiwa perkembangan dengan pertumbuhan terjadi secara sinkron sebab perkembangan itu berkaitan dengan pematangan fungsi organ/individu sedangkan pertumbuhan mempunyai dampak terhadap aspek fisik. ${ }^{9}$ Perkembangan dapat di tinjau dari berbagai aspek yaitu : aspek fisik (perkembangan dapat berupa perkembangan motorik kasar dan motorik halus), aspek mental ( berupa kegiatan berpikir yang sederhana sampai kompleks), aspek emosional (berhubugan dengan perasaan seseorang seperti takut, malu,

9Soetjiningsih, Tumbuh kembang Anak, Buku kedokteran: Jakarta, 1999 hal. 76 
kecewa), aspek sosial (merupakan kemampuan seseorang untuk berhubungan dengan orang lain). ${ }^{10}$

FaktorYangMempengaruhiPerkembanganAnak Adapun faktor langsung yang mempengaruhi perkembangan anak yaitu faktor konsumsi (gizi ), infeksi dan pola asuh anak.

a. Faktor Gizi(Nutrisi)

Gizi amat berperan terhadap perkembangan otak anak sejak anak dari minggu ke -4 pembuahan sampai anak berusia dini. Kebutuhangizi terdiri dari kebutuhanzat gizi makro(energi, protein, lemak) dan kebutuhanzat gizimikro (vitamin, meneral). Pengaruhgizi makromenurut Georgieff dalam Jalal F (2009):

1. Gizi berpengaruh terhadap struktur anatomi otak yang mempengaruhi sel syaraf. Dalam hal ini gizi bekerja melalui proses pembelahan sel-sel syaraf yang akan menentukanjumlah dari selsel syaraf yang dibentuk dan melalui pertumbuhan sel-sel syaraf yang akan menetukan ukuran sel syaraf menuju terbentuknya sel syaraf dengan komponennya yang lengkap (dendrit, akson dil) ${ }^{11}$

2. Gizi Berpengaruh terhadap kimiaotak, yaitu pada proses pembentukan jumlah atau konsentrasi neurotransmitter, pembentukan jumlah reseptor dan jumlah pengangkutan neurotransmitter. Zat gizi makro yang amat diperlukan untuk membantu proses kimia otak adalah protein dan lemak. Lebih dari $60 \%$ berat otak adalah lemak, oleh karena itu lemak penting untuk perkembangan otak. Lemak berperan dalam pembentukan myelin, untuk pembentukan sinaps dan membantu proses pembentukan neurotransmitter. Zat gizi yang berperan vital dalam proses tumbuh kembang sel-sel neuron

${ }^{10}$ Masrul, Pengaruh Sumber Daya Pengasuhan terhadap Tumbuh Kembang Bayi Usia6-12bulan pada keluarga etnik Minang Kabau di Pedesaan Propinsi Sumatera Barat, Proposal disertasi, UNAIR: Surabaya, 2003 hal. 65

${ }^{11}$ Jalal.F,Tantangan pembangunan kesehatan dan gizi dalam upayapeningkatan kualitas SDM,CPI,2009 hal. 80 
b. Infeksi

otak untuk bekal kecerdasan bayi yang dilahirkan adalah asam lemak. ${ }^{12}$ Selain zat gizi (asam lemak) ada faktor lainyang berpengaruh terhadap perkembangan anak yaitu infeksi dan pola asuh. ${ }^{13}$

Penyakit infeksi adalah suatu penyakit yang disebabkan oleh kuman penyakit seperti bakteri, virus, ricketsia, jamur, cacingdan sebagainya. Infeksiyang terjadi pada seseorang akan menyebabkan tubuh kehilangan zat gizi sebagai akibat respon metabolik, kehilangan zat gizi melalui saluran pencernaan (malabsorpsi), gangguan utilisasi ditingkat sel dan penurunan nafsu makan. Sebaliknya, pada keadaan sakit kebutuhan zat gizi akan meningkat. Infeksi intrauterin yang sering menyebabkan cacat bawaan adalah TORCH (Tozoplasmosis, Rubella, Cytomegalovirus, Herpes Simplex). Sedangkan infeksi lainnyayangjuga dapat menyebabkanpenyakit padajanin adalah varisela, Coxsasckie, Echovirus, malaria, lues,HIV, polio, campak, listeriosis, leptospira, mikoplasma, virus influensa, dan virus hepatitis. Penyakit infeksi inimerupakansalah satu faktorresiko terjadinya gangguan pertumbuhan dan perkembangan. Penyakit yang sering diderita oleh anak yang dapat memberikan pengaruh terhadap pertumbuhan dan perkembangan anak adalah diare, ISPA, morbili. Selain infeksi faktor lain yang berpengaruh terhadap perkembangananak adalahpola asuh.

c. PolaAsuh

Pola asuh berarti tindakan pengasuhan anak yang dilakukan berulang - ulang sehingga menjadi suatu kebiasaan, maka relevan dikaitkan dengan pengukuran status gizi dalamjangka lama. Polapengasuhananak berupa sikap dan perilaku Ibu

${ }^{12 N a s a r}$ S.S, Nutrisi untuk Cerdas di akses dari http:/ / www.google.com diakses pada tanggal 14 April2019

${ }^{13}$ Hulock. Elizabets. B,Perkembangan Anak, PT Erlangga: Jakarta. 2007 hal.145 
atau pengasuh lain dalam hal kedekatannyadengan anak, memberikanmakan,merawat, kebersihan, memberi kasih sayang dan sebagainya. Kesemuanya berhubungan dengan keadaan Ibu dalam hal kesehatan (fisik danmental),status gizi, pendidikan umum, pengetahuan dan keterampilan tentang pengasuhan anak yang baik, peran dalam keluarga atau dimasyarakat, sifat pekerjaan sehari-hari, adat kebiasaan keluarga dan masyarakat, dan sebagainya dari si Ibu atau pengasuh anak.14 Para peneliti di Amerika Serikat menunjukkan bahwa anak yang tidak banyak distimulasi maka otaknya akan lebih kecil 30 persen dibandingkan anak lain yang mendapatkan rangsangan secara optimal. Untuk itu diperlukan penilaian terhadap perkembangan anak agar gangguan terhadap perkembangan anak dapat diketahui lebih cepat.

\section{PEMAHAMAN ORANG TUA TERHADAP STUNTING}

Menurut Notoatmodjo pengetahuan merupakan hasil tahu dan terjadi setelah orang melakukan pengindraan terhadap obyek tertentu. Pengindraan terjadi melalui panca indra manusia, yaitu penciuman, penglihatan, pendengaran dan raba. Pengetahuan adalah keseluruhan gagasan, ide, yang dimiliki manusai tentang duni seisinya termasuk manusia dan kehidupannya. Pengetahuan sendiri biasanya didapatkan dari informasi baik yang didapatkan dari pendidikan formal maupun informasi lain seperti radio, TV, internet, koran, majalah, penyuluhan dll. Tingkat pendidikan mempengaruhi seseorang dalam menerima informasi. Orang dengan tingkat pendidikan yang lebih baik akan lebih mudah dalam menerima informasi daripada orang dengan tingkat pendidikan yang kurang. Informasi tersebut dijadikan sebagai bekal ibu untuk mengasuh balitanya dalam kehidupan sehari hari. Persepsi itu sendiri dapat diartikan sebagai cara pandang

${ }^{14}$ Masrul, Pengaruh Sumber Daya Pengasuhan terhadap Tumbuh Kembang Bayi Usia 6-12 bulan pada keluarga etnik Minang Kabau di Pedesaan Propinsi Sumatera Barat, Proposal disertasi, UNAIR: Surabaya, 2003 hal. 90 
seseorang terhadap sesuatu setelah mendapatkan pengetahuan baik secara langsung maupun tidak langsung. ${ }^{15}$

Pengetahuan sangat erat hubungannya dengan pendidikan, dimana dapat diasumsikan bahwa dengan pendidikan yang tinggi maka orang tersebut akan semakin luas pula pengetahuannya. Pendidikan yang rendah tidak menjamin seorang ibu tidak mempunyai pengetahuan yang cukup mengenai gizi keluarganya. Adanya rasa ingin tahu yang tinggi dapat mempengaruhi ibu dalam mendapatkan informasi mengenai makanan yang tepat untuk anak.16 Peningkatan pengetahuan tidak mutlak diperoleh dari pendidikan formal saja, akan tetapi dapat diperoleh melalui pendidikan non-formal. Pengetahuan seseorang tentang suatu objek mengandung dua aspek yaitu aspek aspek positif dan aspek negatif. Kedua aspek ini yang akan menentukan sikap seseorang, semakin banyak aspek positif dan dan objek yang diketahui, maka akan menimbulkan sikap makin positif terhadap objek tertentu. ${ }^{17}$

Menurut Sunaryo, sikap merupakan kesiapan merespons yang sifatnya positif atau negatif terhadap suatu objek atau situasi secara konsisten.18 Sikap merupakan kecenderungan bertindak dari individu berupa respons tertutup terhadapa stimulus ataupun objek tertentu. Sikap menunjukkan adanya kesesuaian reaksi terhadap stimulus yang sudah melibatkan faktor pendapat dan emosi seseorang. Jadi sikap bukanlah suatu tindakan ataupun aktifitas, akan tetapi merupakan sebuah kecenderungan untuk melakukan tindakan atau perilaku atau peran. Menurut Nursalam, sikap seseorang dapat dipengaruhi oleh beberapa faktor yaitu faktor umur, pekerjaan, pendidikan dan paritas. Jika sebagian dari responden memiliki sikap yang negatif, makan tindakan dan

\footnotetext{
${ }^{15}$ Notoatmodjo,Promosi kesehatan teori dan aplikasi, Jakarta: Rineka Cipta. 2005 hal. 89

16Rakhmawati NZ,Hubungan pengetahuan dan sikap ibu dalam pemberian makanan pada anak usia 12-24 bulan (skripsi). Semarang: Universitas Diponegoro. 2013 hal. 89

${ }^{17}$ Notoatmojo S. Promosi kesehatan dan perilaku kesehatan. Jakarta: Rineka Cipta; 2012 hal. 105

18Sunaryo. Psikologi untuk keperawatan. Jakarta: EGC;2004 hal. 58
} 
perilakunya akan cenderung negatif, sehingga masalah gizi pada anak akan terjadi. ${ }^{19}$

Rendahnya tingkat pengetahuan dan tidak terdistribusikan pengetahuan kesehatan dengan baik tentu akan berdampak pada terbatasnya pengetahuan ibu tentang kesehatan, gizi termasuk stunting. Kesalahan persepsi dan rendahnya pengetahuan ibu tentu akan berdampak pada perilaku ibu khususnya perilaku kesehatan dan perilaku pemberian makan pada anak. Kejadian stunting pada anakusiadini terkait dengan asupan zat gizi pada anak. Asupan zat gizi yang dimakan oleh anak sehari hari tergantung dari ibunya sehingga ibu mempunyai peran yang penting terhadap perubahan perubahan masukan zat gizi pada anak. Hasil ini sama dengan penelitian yang dilakukan oleh Ni'mah dan Muniroh yang dilakukan pada balita keluarga miskin di Bojonegoro. Hasil penelitian menunjukkan bahwa tidak ada hubungan antara tingkat pengetahuan ibu dengan wasting dan stunting; dalam penelitian ini masalah wasting lebih banyak terjadi pada ibu dengan tingkat pengetahuan yang kurang $(16,7 \%)$, sedangkan stunting lebih banyak pada ibu dengan pengetahuan yang baik (50\%).

\section{BIMBINGAN DAN PENYULUHAN GIZI TERHADAP ORANG TUA}

Pengetahuan ibu yang baik tentang gizi akan berdampak positif terhadap pola perkembangan anak. Hal ini sependapat bahwa hubungan antara pengetahuan orang tua dengan status gizi balita sangat mempengaruhi cara orang tua memperhatikan gizi pada anak usia dini. Pola asuh ibu terhadap anak yang baik merupakan hal yang sangat penting, karena akan mempengaruhi proses tumbuh kembang balita. ${ }^{20}$ Perkemabngan anak juga dipengaruhi oleh orang tua dalam memberikan pengasuhan. Hal ini sesuai dengan pernyataan

${ }^{19}$ Nursalam,Konsep dan penerapan metodologi penelitian ilmu keperawatan, Jakarta: Salemba Medika. 2008 hal. 121

${ }^{20}$ Linda. O, Hubungan Peendidikan dan Pekerjaan Orang Tua Serta Pola Asuh Dengan Status Gizi Balita Di Kota dan Kabupaten Tangeran, Banten, Jurnal Kesehatan: Jakarta 2011 hal. 137 
bahwa ada hubungan antara pola asuh dengan status gizi anak balita. ${ }^{21}$

Salah satu upaya dalam pencegahan Stunting pada anak usia dini yakni melalui peningkatan pengetahuan, sikap dan perilaku tentang konseling gizi. Konseling gizi adalah suatu proses komunikasi interpersonal/ dua arah antara konselor dan klien (Orang Tua) untuk membantu klien mengenali, mengatasi dan membuat keputusan yang benar dalam mengatasi masalah gizi pada anak usia dini. Penelitian Desy yang menyatakan bahwa pemberian konseling gizi dapat meningkatkan pengetahuan, sikap, dan perilaku ibu tentang pemberian makan pada balita gizi buruk.22 Salah satu pelayanan kesehatan yang menyediakan jasa konseling gizi adalah Puskesmas.

Perlunya perhatian lebih dalam tumbuh kembang di usia dini didasarkan fakta bahwa Stunting disebabkan karena kurangnya kesehatan dan gizi yang terjadi pada masa emas ini. Anak usia dini memerlukan gizi pada makanan yang berbeda-beda sesuai dengan umurnya. Pengaruh gizi kurang pada masa usia dini yang diteliti dikalangan anak-anak Jamaica menunjukkan bahwa setelah umur 6-10 tahun, IQ anak-anak yang menderita gizi kurang pada masa usia dini lebih rendah daripada IQ anak-anak yang cukup gizi pada masa bayinya. Menurut UNICEF (1998) gizi kurang pada anak usia dini disebabkan oleh beberapa faktor yang kemudian di klasifikasikan sebagai penyebab langsung dan penyebab tidak langsung, pokok masalah dan akar masalah. Penyebab langsung dari gizi kurang yakni asupan makanan dan penyakit infeksi. Sedangkan penyebab tidak langsungnya yakni tidak cukup persediaan pangan, pola asuh anak tidak memadai dan sanitasi dan air bersih/ pelayanan kesehatan dasar tidak mamadai. Kemudian terdapat pula pokok masalah dan akar masalah yang terdiri dari kurangnya pemberdayaan

${ }^{21}$ Istiari.T,Menanti Buah Hati, Yogyakarta: Persindo, 2000 hal. 112

${ }^{22}$ Sofiyana. D, Perbedaan Pengetahuan, Sikap Dan Perilaku Sebelum Dan Setelah Konseling Gizi Pada Ibu Balita Gizi Buruk, 2012, hal. 20-25. 
wanita dan keluarga, kurangnya pemanfaatan sumber daya masyarakat dan krisis ekonomi, politik, dan sosial. ${ }^{23}$

Kegiatan yang dapat dilakukan dalam mengurangi praktik pemberian makan yang kurang tepat adalah dengan memberikan intervensi terhadap Ibu. Intervensi gizi merupakan bagian dari program terpadu pengembangan anak usia dini. Konseling tentang pertumbuhan dan pemberian makan pada anak merupakan salah satu bentuk intervensi yang dapat mengurangi praktik gizi yang tidak tepat akibat rendahnya pengetahuan tentang gizi yang dimiliki Ibu. Konseling merupakan pendekatan komunikasi interpersonal yang sering digunakan dalam peningkatan pengetahuan dan perubahan sikap serta perilaku dalam bidang kesehatan. ${ }^{24}$ Konseling tersebut biasa dilakukan di meja empat posyandu dan pojok gizi di Puskesmas.

\section{E. SIMPULAN}

Kegiatan Bimbingan dan Penyuluhan terhadap orang tua untuk mencegah Stunting dengan memberikan pengetahuan dan pemahaman agarmempunyai pengetahuan dan persepsi yang sesuai untuk mencegah Stunting sejak usia dini. Orang tua dengan pengetahuan tentang pentingnya kesehatan gizi dan pencegahan Stunting menjadikan pengetahuan untuk menjaga gizi seimbang pada anak usia dini. Hasil studi merekomendasikan bahwa perlu ditingkatkan pengetahuan gizi kepada ibu khususnya ibu dengan anak yang menderita stunting sehingga terjadi peningkatan, perbaikan pola asuh dan pola makan anak.

Oleh karena itu, untuk mencegah terjadinya stunting pada anak, orang tua perlu dilakukan bimbingan dan penyuluhan tentang mengonsumsi asupan gizi yang layak, terutama selama masa kehamilan hingga anak lahir dan berusia 18 bulan. Pada dasarnya, kelangsungan hidup dan kesehatan anak tidak dapat dipisahkan dari kesehatan ibu. Asupan zat gizi yang rendah dipengaruhi oleh pola asuh, Jakarta. 2000

${ }^{23}$ Unicef, B. d, Laporan Indonesia untuk persiapan end decade goa,

${ }^{24}$ Nurhayati. E, Bimbingan konseling dan psikologi inovatif, Yogyakarta: Pustaka Belajar. 2011 hal. 163 
salah satunya adalah perilaku pemberian makan yang tidak tepat.

\section{DAFTAR PUSTAKA}

Adani, V. 2016. Pangestuti, D. R. \& Raflihudin, M. Z. Hubungan asupan makanan (karbohidrat, protein, dan lemak) dengan status gizi bayi dan balita ( studi pada taman penitipan anak lusendra Kota Semarang Tahun 2016). Jurnal Kesehatan Masyarakat.

Astari Ld. 2005. Nasoetion A \& Dwiriani CM, Hubungan Antara Keluarga dan Anak dalam Menangani Masalah Stunting Usia 612 Bulan, Media Gizi Dan Keluarga.; 29

Astari Ld. 2006. Nasoetion A \& Dwiriani Cm, Correlation between breastmilk consumption wirh stunting prevalences among children 6-12 months old in bogor municipality, Media Gizi Dan Keluarga.

El Taguri A, Betilmal I, Mahmud Sm, Ahmed Am, Goulet O, Galan P \& Hercberg S. 2008. Risk factor for stunting among under-fives in Libya, Public Health Nutrition

Handayani, Oktia WK. Rahayu, Sri R. Hermawati. 2018. Efektifitas Kepemimpinan dan Optimalisasi Potensi Lokal untuk Membangun Lingkungan Sadar Nutrisi, Jurnal Kesehatan Masyarakat

Hulock. Elizabets. B. 2007.Perkembangan Anak, PT Erlangga: Jakarta

Istiari.T. 2000. Menanti Buah Hati, Yogyakarta: Persindo

Jalal. F. 2009. Tantangan pembangunan kesehatan dan gizi dalam upay apeningkatan kualitas SDM,CPIKementrian Kesehatan RI Keputusan Menteri Kesehatan Republik Indonesia. 2011. Standar Antropometri Penilaian Status Gizi Anak. Jakarta 
Linda. O. 2011. Hubungan Peendidikan dan Pekerjaan Orang Tua Serta Pola Asuh Dengan Status Gizi Balita Di Kota dan Kabupaten Tangeran, Banten, Jurnal Kesehatan: Jakarta

Masrul. 2003.Pengaruh Sumber Daya Pengasuhan terhadap Tumbuh Kembang Bayi Usia 6-12 bulan pada keluarga etnik Minang Kabau di Pedesaan Propinsi Sumatera Barat, Proposal disertasi, UNAIR: Surabaya

Nasar S.S, Nutrisi untuk Cerdas di akses dari http:// www.google.com diakses pada tanggal 14 April 2019

Notoatmodjo. 2005.Promosi kesehatan teori dan aplikasi, Jakarta: Rineka Cipta

Nurhayati. E. 2011.Bimbingan konseling dan psikologi inovatif, Yogyakarta: Pustaka Belajar

Nursalam. 2008. Konsep dan penerapan metodologi penelitian ilmu keperawatan, Jakarta: Salemba Medika

Rakhmawati NZ. 2013. Hubungan pengetahuan dan sikap ibu dalam pemberian makanan pada anak usia 12-24 bulan (skripsi). Semarang: Universitas Diponegoro

Soetjiningsih. 1999.Tumbuh kembang Anak, Buku kedokteran: Jakarta

Sofiyana. D. 2012. Perbedaan Pengetahuan, Sikap Dan Perilaku Sebelum Dan Setelah Konseling Gizi Pada Ibu Balita Gizi Buruk

Sunaryo. 2004. Psikologi untuk keperawatan. Jakarta: EGC

Unicef, B. D. 2000. Laporan Indonesia untuk persiapan end decade goa, Jakarta 